\title{
Hardiness in relation to organisational commitment in the Human Resource Management field
}

\author{
Author: \\ Nadia Ferreira ${ }^{1}$ \\ Affiliation: \\ ${ }^{1}$ Department of Human \\ Resource Management, \\ University of South Africa, \\ South Africa \\ Correspondence to: \\ Nadia Ferreira \\ Email: \\ ferren@unisa.ac.za \\ Postal address \\ PO Box 392, UNISA 0003, \\ South Africa \\ Dates: \\ Received: 03 Oct. 2011 \\ Accepted: 19 Apr. 2012 \\ Published: 26 Sept. 2012 \\ How to cite this article: \\ Ferreira, N. (2012). \\ Hardiness in relation to \\ organisational commitment \\ in the Human Resource \\ Management field. SA \\ Journal of Human Resource \\ Management/SA Tydskrif vir \\ Menslikehulpbronbestuur, \\ 10(2), Art. \#418, 10 pages. \\ http://dx.doi.org/10.4102/ \\ sajhrm.v10i2.418
}

(C) 2012. The Authors.

Licensee: AOSIS

OpenJournals. This work

is licensed under the

Creative Commons

Attribution License.
Orientation: Employees' hardiness is increasingly recognised as an aspect of their well-being and feelings of career success. Psychological well-being and feelings of subjective career success have positive implications for the motivation, satisfaction, performance and commitment of young talented staff.

Research purpose: The study empirically investigated the relationship between an individual's hardiness (measured by the Personal Views Survey II [PVS-II]) and organisational commitment (measured by the Organisational Commitment Scale).

Motivation for the study: Research on an individual's hardiness profile as an aspect of their career well-being and success and how these attributes influence their psychological attachment to the organisation, is needed to guide human resource career development support practices aimed at retaining valuable staff.

Research design, approach and method: A quantitative survey was conducted on a convenience sample of predominantly Black (92.2\%) and female (71\%) employed adults $(N=355)$ at managerial and staff levels in the human resource management field.

Main findings: Correlational and multiple regression analyses revealed a number of significant relationships between the two variables.

Practical/managerial implications: Managers and human resource practitioners need to recognise how people's hardiness relates to their sense of psychological attachment to the organisation. Organisations concerned with the retention and well-being of their equity staff members need to find a way to enhance and develop their hardiness and commitment.

Contribution/value-add: The research contributes new insights into and knowledge of the factors that influence their employees' hardiness and how these relate to their organisational commitment. The results may be used to inform career development support interventions that aim to increase employees' sense of career well-being and success.

\section{Introduction}

\section{Key focus of the study}

This study focuses on how employees' hardiness (as an aspect of their general psychological career well-being) relate to their organisational commitment. In the present turbulent times the nature of work and careers are changing constantly and at an increasing rate (Sparks, Faragher \& Cooper, 2001). Heightened feelings of insecurity have led to higher stress and anxiety levels (Avey, Luthans, Smith \& Palmer, 2010; Meyer \& Maltin, 2010). Organisations concerned about the retention of young talent in times of skills shortages are becoming increasingly aware of how the psychological career well-being and subjective work experiences of their high-performing staff are influencing their organisational commitment, motivation, satisfaction, performance and retention (Russ \& McNeilly, 1995).

\section{Background to the study}

An employee's psychological well-being has been identified as a predictor of risk behaviour, which in turn affects the individual's sense of job security and career behaviour (Emberland \& Rundmo, 2010). Feelings of job insecurity are likely to trigger anxiety and stress within the individual, which might affect the ability to control and deal with challenging situations within the organisation. Research indicates that developing individuals' hardiness (i.e., their ability to deal resourcefully with challenging and demanding circumstances) may lead to higher levels of performance, a higher ability to deal proactively with stress, and may help employees to be more resilient (Maddi, 2006; Maddi \& Khoshaba, 2005). Job insecurity, anxiety and stress in the workplace affect employees' morale, performance and organisational commitment (Carr, Kelley, Keaton \& Albrecht, 2011; Emberland \& Rundmo, 2010; Meyer \& Maltin, 2010). Employees who are 
highly committed are less likely to leave their organisation when compared to less committed individuals (Coetzee, Bergh \& Schreuder, 2010; Ferreira, Basson \& Coetzee, 2010; Mathieu \& Zajac, 1990). Highly committed individuals might be less absent from work, perform more effectively (Meyer \& Maltin, 2010), and be better organisational citizens (Meyer, Stanley, Herscovitch \& Topolnytsky, 2002).

A further trend in the world of work is that employers are concerned about the organisational commitment of their talented staff (Ferreira et al., 2010). Current changes, such as globalisation, fast changing technology and the changing nature of psychological contracts in career and organisational contexts are causing individuals to identify diverse goals and expectations concerning their job satisfaction (Meyer \& Maltin, 2010). Individuals are increasingly taking on a more active role as the career agent in managing their career development and satisfaction. Commitment to the organisation seems to be associated directly with how people experience (positively or negatively) the manner in which they have been treated during times of change (Baruch, 2006; Holbeche, 1997; Hughes \& Half, 2009). Employees who are highly committed to the organisation may be better able to withstand stressors, provided that those stressors do not directly challenge their commitment, motivation and career well-being (Meyer \& Maltin, 2010). Therefore, managers or supervisors can perhaps enhance an employee's career well-being by reinforcing positive forms of commitment and motivation.

\section{Trends from the research literature}

The world of work is changing at a very high speed. The technological, economical and societal changes in developing economies are occurring at a faster pace than ever before, and the demand for young, talented staff (especially form previous disadvantaged groups) is increasing. Attracting and retaining talented employees is an enormous challenge faced by organisations. However, employees are likely to remain with their current organisation if they have positive work experiences, feel satisfied with their job, and experience a high quality of work life (Rathi, Rastogi \& Rangnekar, 2011).

Employees' experiences of subjective career success have been associated with their sense of well-being at work (Coetzee \& Bergh, 2009; Nabi, 2001; Schreuder \& Coetzee, 2011). The concept of career well-being has been used by Kidd (2008) to measure employee's subjective career experiences as indicated by their positive and negative feelings about their careers. Other researchers use more general measures of subjective well-being (including happiness and satisfaction) in the careers context (Coetzee \& Bergh, 2009; Gottfredson \& Duffy, 2008). In order to thrive and to survive in a continuously changing environment, organisations need employees who are in good mental and physical health. Individuals' experiences at work, be they physical, emotional, social or spiritual in nature, affect their well-being in the workplace (Hart, 1999; Kelloway \& Barling, 1991; Kelloway, Innes, Barling, Francis \& Turner, 2010).
Several studies headed by Kobasa and colleagues (Kobasa, Maddi \& Kahn, 1982; Kobasa \& Pucceti, 1983) have found that hardiness has a comparable protecting effect, as well as a moderating effect on stress that forms part of the wellbeing of employees. Analyses of these investigations have led Kobasa (1982) to propose that hardy individuals have a clear sense of direction, a dynamic approach in demanding situations, and a sense of self-belief and control that moderate the intensity of possible threats and dangers (Zakin, Solomon \& Neria, 2003) such as career uncertainty in the current and more turbulent career context. Commitment to organisations seems to be directly associated with how well people feel about their psychological needs being met, being respected and recognised by organisations (Hughes \& Half, 2009), and what their career goals look like at a specific time within the organisations (Baruch, 2006; Holbeche, 1997).

\section{Research objective}

The present study focused on how individuals' hardiness influences their psychological attachment or commitment to the organisation. By identifying the relationship between the variables, recommendations can be made for enhancing human resource career development support practices as a critical element of enhancing the career well-being of employees as an aspect of retaining key talent.

\section{Potential value-add of the study}

This article extends research on the hardiness attributes that influence people's psychological attachment (commitment) to their organisations. Assessing whether people's hardiness is related to their organisational commitment may provide valuable information for human resource managers and practitioners concerned with career development support practices for the enhancement of employee well-being.

\section{Theory \\ Hardiness}

In their original work, Kobasa et al. (1982) described hardiness as a collection of personality characteristics that function as a flexible resource during encounters with demanding life events. A number of researchers also adopted this definition of hardiness (Breed, Cilliers \& Visser, 2006; Kobasa, 1979; Kobasa et al., 1982; Kobasa, Maddi \& Zola, 1985). Individuals high in hardiness tend to actively involve (commit) themselves in (to) whatever they are doing. They also believe and act as if they can influence (control) the events forming their lives, and consider change to be not only normal but also a stimulus (challenge) to development (Azeem, 2010; Delahaij, Gailard \& Van Dam, 2010; Hystad, Eid, Laberg, Johnsen \& Bartone, 2010; Kobasa et al., 1985; Zhang, 2010).

Commitment: Commitment in terms of the hardiness construct refers to individuals who strongly believe in the certainty, significance, and interest value of who they are and what they are doing. Hardy-committed individuals therefore show the tendency to involve themselves fully in a number of life situations, including work, family, interpersonal 
relationships, and social institutions (Kobasa, 1987, p. 6). Hardy-commitment engenders feelings of excitement along with a strong sense of community and motivation to remain engaged during difficult times (Kobasa, 1982; Kobasa, 1985; Sheard \& Golby, 2007).

Control: Control in terms of the hardiness construct refers to an enhanced motivation to engage in effortful coping because it predisposes the individual to view stressors as changeable (Kobasa, 1982; Maddi, 2002; Maddi \& Kobasa, 1984). Hardy individuals feel that attempting to control or change a demanding or undesirable situation (rather than fatalistically accepting the outcome) falls within their scope of personal responsibility. Control enables individuals to experience many stressful life events as expected consequences of their own activities and, thereby, guide them in the right direction and appropriate manipulation of the situation (Kobasa, 1982, p. 7). When faced with difficulties, individuals with high control are more likely to feel capable of acting effectively on their own. They do not merely take situations at face value: they reflect on how to change situations to their advantage (Maddi \& Kobasa, 1984).

Challenge: Challenge in terms of the hardiness construct refers to a zest for facing up to (or even seeking out) difficult experiences because they are seen as opportunities for personal growth rather than as potential threats to security (Maddi et al., 2002). Thus, individuals who expect to thrive must learn to embrace the difficulty of 'authentic living', drawing strength from difficulties previously faced and overcome successfully rather than looking for ways to avoid stressful events (Carr et al., 2011).

Individuals who thrive in times of challenge are motivated to become catalysts in their environments and to practise responding to the unexpected. They explore their surroundings thoroughly in an ongoing search for new and interesting experiences. As a result, they know where to turn to for resources to aid them in coping with stress. Highly challenged individuals are characterised by cognitive flexibility and tolerance for ambiguity. This allows them to integrate unexpected or otherwise stressful events more easily than their colleagues (Kobasa, 1982; Maddi, 1999).

The combination of hardy-commitment, control and challenge constitutes existential courage and motivation within individuals. To tolerate and resolve stressful circumstances, one must see them as, (1) natural developmental pressures rather than catastrophic setbacks (challenge helps here), (2) resolvable rather than unmanageable (control helps here) and (3) worth investing in rather than to be avoided (commitment helps here). Together, the three Cs (commitment, control and challenge) of hardiness are very close to what existential thinkers, such as Tillich (1952), meant by the 'courage' to be.

According to Maddi (2004), the stronger the three Cs (commitment, control and challenge) of hardiness, the greater the signs of surviving and thriving on the catastrophic changes that might occur. This means that if an individual has the ability to control change within his or her career, he or she will survive no matter what the outcome might be. Hardiness has emerged as an important stress resilience construct that has attracted a high level of continued research attention (Maddi \& Khoshaba, 2005).

\section{Organisational commitment}

In the context of this study, organisational commitment is defined as a psychological connection individuals have with their organisation, characterised by strong identification with the organisation and a yearning to contribute towards the accomplishment of organisational goals (Meyer \& Allen, 1997). Meyer and Allen's (1991) three-component model of organisational commitments is therefore relevant to this research. Meyer and Allen (1991) define organisational commitment as reflecting three aspects namely, (1) affective commitment, (2) continuance commitment and (3) normative commitment. Organisational commitment therefore reflects an affective attitude to the organisation, acknowledgement of the consequences of leaving the organisations, and an ethical responsibility to stay with the organisations (Meyer \& Allen, 1991).

The concept of organisational commitment has attracted considerable interest in an attempt to understand and clarify the intensity and stability of an employee's dedication to the organisation (Mester, Visser, Roodt \& Kellerman, 2003). The level of employees' organisational commitment will possibly ensure that they are better suited to receive both extrinsic rewards (which includes remuneration and benefits) and psychological rewards (which essentalliy includes job satisfaction and associations with fellow employees) related to associations (Coetzee \& Bergh, 2009). Organisations appreciate commitment on the part of their staff. It is generally assumed that organisational commitment reduces adandonment behaviours, which include tardiness and turnover. In addition, employees who are committed to their organisations may possibly be more willing to participate in 'extra-role' activities, such as being creative or innovative, which frequently guarantee an organisation's competitiveness in the market (Barnett \& Bradley, 2007; Katz \& Kahn, 1978). According to Gbadamosi (2003), the more favourable individuals' attitudes towards the organisation, the greater their acceptance of the goals of the organisation and their willingness to exert more efforts on behalf of the organisation.

Individuals who are affectively committed or dedicated at an emotional level usually remain with the organisation because they see their individual employment relationship as harmonious; they take ownership of the goals and values of the organisation. Affective commitment develops because the individual identifies with the organisation and internalises the principles and standards of the organisation (Beck \& Wilson, 2000).

Continuance commitment, is an 'awareness of the costs associated with leaving the organisation' (Meyer \& Allen, 
1997, p. 11). Because individuals' awareness or consideration of expenses and threats are linked to leaving the organisation, continuance commitment is considered to be calculative (Meyer \& Allen, 1997). Meyer and Allen (1991) also indicated that individuals whose most important connection to the organisation is based on continuance commitment stay because they need to. Individuals remain with a specific organisation because of the money they earn in return for the work they do, not because they want to. This differs from affective commitment where individuals remain with an organisation because they want to and because they are familiar with it and its principles.

Normative commitment can be explained as a sense of responsibility to continue employment with a specific organisation (Meyer \& Allen, 1997). The internalised normative idea of responsibility and commitment allows individuals to value their continued membership of a specific organisation (Allen \& Meyer, 1990). The normative element is seen as the commitment individuals think morally about; regarding their right to remain with a specific organisation, in spite of how much status improvement or fulfilment the organisation provides the individual over the years (March \& Mannari, 1977).

\section{Relationship between hardiness and organisational commitment}

In terms of the present study, it is hypothesised that individuals with high levels of hardiness will be positively and significantly committed to organisations. Several studies suggest that hardy people in general appraise stressful events differently and gravitate toward more active coping strategies. Hardy individuals report events as less threatening and feel more optimistic about their ability to cope (Florian, Mikulincer \& Taubman, 1995; Rhodewalt \& Zone, 1989). Hardy people also use adaptive (transformational) controlling strategies such as problem-focused coping and support-seeking, and are less likely to use passive (regressive) controlling strategies such as emotion-focused controlling and distancing (Mills, 2000; Westman, 1990; Wiebe, 1991). According to Saks (2006), hardy individuals are likely to be committed and engaged with the people and events that surround them. Sezgin (2009) also indicated hardiness as a predictor of all three components of organisational commitment. Based on the preceding research findings, the following research hypothesis is made:

- Hypothesis 1: Hardiness is significantly and positively related to an individual's level of organisational commitment.

The hypothesised theoretical relationship between hardiness (commitment, control and challenge) and organisational commitment (affective commitment, continuance commitment and normative commitment) is illustrated in Figure 1.

\section{Research design Research approach}

A quantitative survey design was used to achieve the research objective.

\section{Research method}

\section{Research participants}

The participants were a convenience sample of 355 employed adults at managerial and staff levels who were enrolled for a human resource management programme at a distance higher education institution. The sample was predominantly Black $(92.2 \%)$ and female $(71 \%)$. The single $(54.6 \%)$ and married $(37.7 \%)$ participants were mostly in their early adulthood life stage (26-40 years) (63.9\%). Participants were employed fulltime and occupied relatively high-level positions at senior, and middle management level (14\%) and staff level (76.1\%) in the human resource management field.

\section{Measuring instruments}

The Personal Views Survey II (PVS-II) (Maddi \& Kobasa, 1984) and the Organisational Commitment Scale (OCS) (Meyer \& Allen, 1997) were used to measure the variables of concern to this study.

Personal Views Survey II (PVS-II): The PVS-II (Maddi, 1987) is a self-rated multi-factorial measure for hardiness and contains 50 items and three subscales (commitment, control and challenge). A 4-point Likert-type scale was used for subject responses to each of the 50 items. Factor analysis by Maddi (1987) confirmed the construct validity of the PVS-II. In terms of internal consistency reliability, Maddi (1987) reports the following Cronbach alpha coefficients: .70 to .75 for commitment; .61 to .84 for control; .60 to .71 for challenge and .80 to .88 for total hardiness.

Organisational Commitment Scale (OCS): The Organisational Commitment Scale (Meyer \& Allen, 1997) is a multi-factorial measure for affective commitment

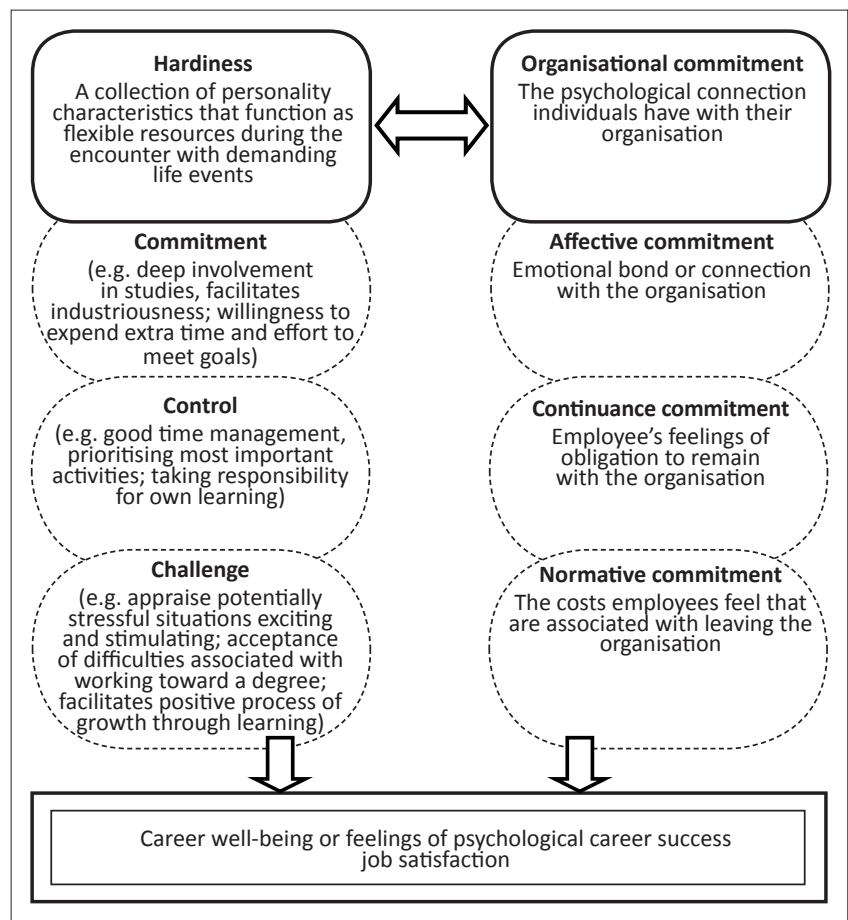

FIGURE 1: Theoretical relationship between hardiness and organisational commitment. 
(8 items), continuance commitment (9 items) and normative commitment (6 items) on a 7-point Likert type scale. The following internal consistency reliability estimates (Cronbach's alphas) are reported for affective commitment (.82), continuance commitment (.74) and normative commitment (.83). Studies by Coetzee, Schreuder and Tladinyane (2007), Ferreira (2009), Lumley (2010) and Lumley, Coetzee, Tladinyane and Ferreira (2011) confirmed the reliability and validity of the OCS in the South African context.

\section{Research procedure}

The participants attended a three-day study school. The questionnaires were administered in a group session to the participants and collected as soon as they had been completed. Each questionnaire included a covering letter inviting subjects to participate voluntarily in the study and assuring them that their individual responses would remain confidential and be used for research purposes only. In terms of ethics, permission for the research was obtained from the institution's research ethics committee. A total of 396 students attended the study school and a sample of 355 usable questionnaires was returned, yielding a response rate of $89.6 \%$.

\section{Statistical analysis}

The data analysis procedures chosen for this research were based on their applicability to the nature of the research design. The Rasch analysis was used to evaluate the unidimensionality of the two scales by calculating the infit and outfit chi-square statistics to gain an indication of how well the items measured the underlying constructs. Cronbach's alpha coefficients were calculated to determine the internal consistency reliability of the two measures. Both person and item separation indexes had to be at least 2.00 for an instrument to be regarded as useful (Fox \& Jones, 1998). Descriptive and inferential statistics were used to analyse the data. Pearson product-moment correlations and multiple regression analysis were performed to test the research hypothesis.

Although a cut-off point of $p \leq .05$ was set, a practical effect size of $r \geq .30$ (medium effect, Cohen 1992) was also considered for the correlational analyses to be able to interpret the practical significance of the findings. In terms of the multiple regression analyses, the value of adjusted $R^{2}$ was used to determine the proportion of the total variance of the dependent variable (OCS) that is explained by the independent variable (PVS-II). The $F$-test was used to test whether there was a significant regression $(p \leq .05)$ between the independent and dependent variables.

\section{Results}

Table 1 indicates the internal consistency of the measurements in terms of the item and person separation index and reliability index, person reliability in terms of Cronbach's alpha coefficients, the average measure of each dimension per person and item, as well as the infit and outfit statistics for each dimension per person and item infit and outfit statistics for each dimension.

Table 1 shows acceptableitem reliability for all the dimensions, indicating that these items differentiated well amongst the measured variables (equal to or greater than .80). The item separation for all the dimensions were sufficient compared to the guideline of at least 2.00 as indicated by Fox and Jones (1998). The person separation index for all the dimensions were somewhat lower than the proposed guideline (> 2.00). Cronbach's alpha coefficients for all the dimensions were acceptable, except for challenge (.59) and affective commitment (.56) that were somewhat lower than the cut-off point of 0.70 . The commitment dimension shows the highest person average measure $(-.95, \mathrm{SD}=.74)$ and the normative commitment dimension the lowest average measure

TABLE 1: Person and item reliability: Personal Views Survey II and Organisational Commitment Scale.

\begin{tabular}{|c|c|c|c|c|c|c|c|c|c|c|}
\hline \multirow[t]{2}{*}{ Dimension } & \multirow{2}{*}{$\begin{array}{l}\text { Reliability } \\
\text { dimensions }\end{array}$} & \multicolumn{2}{|c|}{ Average measure } & \multicolumn{2}{|c|}{ Infit } & \multicolumn{2}{|c|}{ Outfit } & \multirow[t]{2}{*}{ Separation } & \multirow[t]{2}{*}{ Reliability } & \multirow[t]{2}{*}{ Alpha } \\
\hline & & Mean & SD & Mean & SD & Mean & SD & & & \\
\hline \multirow[t]{2}{*}{ PVS-II over all scale } & Person & -.55 & .47 & 1.01 & -.10 & 1.01 & -.10 & 2.56 & .87 & .87 \\
\hline & Item & .00 & .62 & 1.01 & .00 & 1.01 & .10 & 9.45 & .99 & - \\
\hline \multirow[t]{2}{*}{ Commitment } & Person & -.95 & .74 & 1.02 & .00 & 1.00 & .00 & 1.76 & .76 & .76 \\
\hline & Item & .00 & .48 & 1.01 & .10 & 1.00 & .10 & 6.78 & .98 & - \\
\hline \multirow[t]{2}{*}{ Control } & Person & -.82 & 0.60 & 1.01 & -.10 & 1.01 & .00 & 1.60 & .72 & .71 \\
\hline & Item & .00 & .47 & 1.01 & .00 & 1.01 & .00 & 6.86 & .98 & - \\
\hline \multirow[t]{2}{*}{ Challenge } & Person & -.05 & .46 & 1.01 & -.10 & 1.01 & -.10 & 1.28 & .62 & .59 \\
\hline & Item & .00 & .62 & 1.00 & -.10 & 1.01 & .10 & 9.86 & .99 & - \\
\hline \multirow[t]{2}{*}{ OCS over all scale } & Person & -.05 & .32 & 1.02 & -.40 & 1.02 & -.40 & 2.30 & .84 & .82 \\
\hline & Item & .00 & .16 & 1.00 & -.20 & 1.02 & .10 & 5.05 & .96 & - \\
\hline \multirow[t]{2}{*}{ Affective commitment } & Person & -.10 & .41 & 1.00 & -.30 & 1.00 & -.20 & 1.43 & .67 & .56 \\
\hline & Item & .00 & .22 & 1.00 & .00 & 1.00 & .00 & 6.57 & .98 & - \\
\hline \multirow[t]{2}{*}{ Normative commitment } & Person & -.02 & .63 & 1.14 & -.20 & 1.13 & -.3 & 1.72 & .75 & .73 \\
\hline & Item & .00 & .15 & 1.01 & -2.2 & 1.13 & -1.6 & 4.05 & .94 & - \\
\hline \multirow[t]{2}{*}{ Continuance commitment } & Person & -.02 & .50 & 1.06 & -.30 & 1.06 & -.20 & 1.87 & .78 & .74 \\
\hline & Item & .00 & .17 & 1.00 & -.30 & 1.06 & .10 & 4.98 & .96 & - \\
\hline
\end{tabular}

$N=355$, sample size of employed adults.

PVS-II, Personal Views Survey II; OCS, Organisational Commitment Scale; SD, standard deviation. 
$(.00, \mathrm{SD}=.15)$. The mean item fit and person fit were acceptable. It is evident that, on average, the responses do not underfit or overfit. Overall, the two measuring instruments were regarded as useful and reliable in interpreting the results.

Means and standard deviations for the PVS-II and OCS variables are shown in Table 2. Participants obtained the highest mean scores on the PVS-II challenge variable $(\mathrm{M}=3.43 ; \mathrm{SD}=5.71)$ and the lowest means core on the control $(\mathrm{M}=2.59 ; \mathrm{SD}=6.47)$ and commitment $(\mathrm{M}=2.31 ; \mathrm{SD}=6.46)$ variables. In terms of the OCS, the participants obtained the highest mean scores on continuance commitment variable $(\mathrm{M}=4.76 ; \mathrm{SD}=9.92)$ and the lowest mean scores on the affective $(\mathrm{M}=4.71 ; \mathrm{SD}=7.28)$ and normative commitment variables $(\mathrm{M}=4.70 ; \mathrm{SD}=7.55)$. Kurtosis coefficients fell within the normality range, ranging between -.09 and .68 . Similarly, the skewness coefficients fell within the normality range, ranging between -.19 and .52 .

\section{Hypothesis testing}

Hypothesis 1 was analysed by firstly performing Pearson product-moment correlations and secondly, by conducting standard multiple regression.

\section{Correlational statistics}

Pearson's product-moment correlations are indicated in Table 3. With the exception of the PVS-II challenge variable and OCS normative commitment variable, all the PVS-II and OCS variables showed significant positive relationships, ranging between $r=.11$ and .25 ( $p \leq .05 ; r \leq .30$, small practical effect size).

Table 3 shows a significant positive relationship between all three hardiness variables; commitment $(r=.20 ; p \leq .05$ small effect), control ( $r=.15$; small effect; $p \leq .05)$ and challenge $(r=.17$; small effect $p \leq .05)$ and affective commitment. In terms of the hardiness variables, commitment $(r=.22$; small effect; $p \leq .05)$, control ( $r=.25$; small effect; $p \leq .05)$ and challenge ( $r=.18$; small effect; $p \leq .05)$ relates significantly and positively with continuance commitment. The hardiness variables commitment $(r=.11$; small effect; $p \leq .05)$ and control ( $r=.14$; small effect; $p \leq .05)$ showed a significant and positive relationship with normative commitment. No other significant associations were identified between the challenge and the normative commitment.

\section{Multiple regression analysis: Personal Views Survey II and Organisational Commitment Scale}

Multiple regressions are indicated in Table 4.

Table 4 shows that the regression of the PVS-II variables upon the OCS affective commitment variable produced a statistically significant model $(F[264.97 ; 51.19]=5.18$; $p \leq .001$ ), accounting for $R^{2}=3 \%$ (small practical effect) of the variance in the affective commitment variable. Only the PVS-II commitment variable significantly and positively predicted the OCS affective commitment variable $(\beta=.16$; $p \leq .00)$.

The PVS-II variables regressed upon the OCS continuance commitment variable produced a statistically significant model $(F[822.05 ; 92.21]=8.92 ; p \leq .001)$, accounting $R^{2}=$ for $6 \%$ (small practical effect) of the variance in the continuance commitment variable. Only the PVS-II challenge $(\beta=.19 ; p \leq .00)$ variable significantly and positively predicted the OCS continuance commitment variable.

The PVS-II variables regressed upon the OCS normative commitment variable produced a statistically significant model $(F[148.50 ; 56.21]=2.64 ; p \leq .001)$, accounting for $R^{2}=1 \%$ (small practical effect) of the variance in the normative commitment variable. Again, only the PVS-II challenge variable $(\beta=.13 ; p \leq .00)$ significantly and positively predicted the OCS normative commitment variable.

In this regard, the correlation and regression results provided support for the research hypothesis (Hypothesis 1) that a significant and positive relationship exists between hardiness and organisational commitment.

TABLE 2: Descriptive statistics: Personal Views Survey II and Organisational Commitment Scale.

\begin{tabular}{|c|c|c|c|c|c|c|c|}
\hline Measuring instruments & Dimensions & Minimum & Maximum & Mean & SD & Skewness & Kurtosis \\
\hline \multirow[t]{3}{*}{ PVS-II } & Commitment & 1.87 & 1.39 & 2.31 & 6.46 & .52 & .02 \\
\hline & Control & 1.91 & 1.37 & 2.59 & 6.47 & .11 & -.17 \\
\hline & Challenge & 2.46 & 1.80 & 3.43 & 5.71 & .45 & -.09 \\
\hline \multirow[t]{3}{*}{ OCS } & Affective commitment & 3.95 & 3.08 & 4.71 & 7.28 & .00 & .68 \\
\hline & Continuance commitment & 4.12 & 3.21 & 4.76 & 9.92 & -.14 & -.66 \\
\hline & Normative commitment & 4.11 & 3.61 & 4.70 & 7.55 & -.19 & -.23 \\
\hline
\end{tabular}

$N=355$, sample size of employed adults.

PVS-II, Personal Views Survey II; OCS, Organisational Commitment Scale; SD, standard deviation.

TABLE 3: Pearson-Product moment correlations: Personal Views Survey II and Organisational Commitment Scale.

\begin{tabular}{|c|c|c|c|c|}
\hline PVS-II & Dimensions & Affective commitment (OCS) & Continuance commitment (OCS) & Normative commitment (OCS) \\
\hline \multirow[t]{3}{*}{ Hardiness } & Commitment & $.20 * *++$ & $.22^{* *}++$ & $.11 *++$ \\
\hline & Control & $.15^{* *++}$ & $.25^{* *++}$ & $.14 * *++$ \\
\hline & Challenge & $.17^{* *++}$ & $.18^{* *}++$ & $n / s$ \\
\hline
\end{tabular}

$N=355$, sample size of employed adults.

PVS-II, Personal Views Survey II; OCS, Organisational Commitment Scale; n/s, not significant.

,$++ r \geq 0.30 \leq 0.49$ (medium practical effect size).

${ }^{*}, p \leq 0.05$ (two-tailed); ${ }^{* *}, p \leq 0.01$ 


\section{Ethical considerations}

The procedures followed in the research adhered to all the ethical requirements that are necessary to ensure ethical responsibility.

Permission to conduct the research was obtained through the Department of Industrial and Organisational Psychology, University of South Africa. To ensure that the researcher meets the ethical requirements, the following ethical principles were adhered to:

- Research was conducted within recognised parameters.

- Approval was obtained from the host institution.

- Both classical and recent resources were used to analyse and describe the concepts.

- Experts in the field of research were consulted to ensure a scientific research process.

- All the resources used were quoted.

- Informed agreement was obtained from participants.

Ethical and employment equity issues have been taken into consideration. Anonymity of the participants has been ensured both during the data collection and analyses of data. The Employment Equity Act (No 55 of 1998), requires all psychological tests and other similar assessments to be valid, reliable, fair, as well as not biased against any employee or any specific group of employees. In order to comply with legislation, care was taken in the choice and administration of the psychometric battery. The validity of items were evaluated, a reliable process was followed during data collection and data was analysed, reported and interpreted in a valid, reliable, fair and unbaised manner.

\section{Trustworthiness}

\section{Reliability}

Reliability was ensured by structuring the research model in order to limit the nuisance variables. The research context was respected at all times. The reliability of a literature review is ensured when other interested academics have access to the literature sources and the theoretical views in the literature.

Reliability of the empirical research is ensured when a truly representative sample is used. In this research, confounding variables were minimised through the sampling procedure and by including instruments of which the reliability has been proven through previous research.

\section{Validity}

Validity was ensured through the use of appropriate and standardised measuring instruments. The measuring instruments were critically examined for their criterionrelated validity (to ensure accurate prediction of scores on the relevant criterion), content validity and construct validity (the extent to which the measuring instruments measure the theoretical constructs they purport to measure).

\section{Discussion}

The study explored the relationship between individuals' hardiness and their organisational commitment. The correlational and multiple regression analyses indicated a number of significant and positive relationships between the variables, which provide valuable pointers about the relationship between the variables.

Overall, the results suggest that participants who experience a sense of control and feel that they are able to handle challenges (hardiness) seem to have a higher level of organisational commitment. The significant relationships observed between the hardy-commitment and affective, continuance and normative commitment components suggest that participants who feel they are highly committed and involved in their doings seem to feel a much stronger emotional bond with the organisation. These participants also appear to feel a high sense of obligation to remain employed in their current organisation. These findings

TABLE 4: Multiple regression analyses: Personal Views Survey II and Organisational Commitment Scale.

\begin{tabular}{|c|c|c|c|c|c|c|c|c|c|c|}
\hline \multirow[t]{2}{*}{ Variable } & \multicolumn{2}{|c|}{$\begin{array}{l}\text { Unstandardised } \\
\text { coefficient }\end{array}$} & \multirow{2}{*}{$\begin{array}{l}\text { Standardised } \\
\text { coefficient } \\
\beta\end{array}$} & \multirow[t]{2}{*}{$t$} & \multirow[t]{2}{*}{$p$} & \multirow[t]{2}{*}{$F$} & \multirow[t]{2}{*}{ Adjusted $R^{2}$} & \multirow[t]{2}{*}{$R$} & \multicolumn{2}{|c|}{$\begin{array}{l}\text { Collinearity } \\
\text { statistics }\end{array}$} \\
\hline & B & SE B & & & & & & & $\mathbf{T}$ & VIF \\
\hline Affective commitment (OCS) & 23.28 & 2.84 & - & 8.20 & 0.00 & $5.18 \dagger$ & $0.03 * * *_{+}$ & 0.21 & - & - \\
\hline Control (PVS-II) & 0.02 & 0.10 & 0.02 & 0.24 & 0.81 & - & - & - & 0.38 & 2.62 \\
\hline Challenge (PVS-II) & 0.06 & 0.08 & 0.05 & 0.72 & 0.47 & - & - & - & 0.62 & 1.60 \\
\hline Continuance commitment (OCS) & 19.25 & 3.82 & - & 5.04 & 0.00 & $8.92 \%$ & $0.06 * * *+$ & 0.27 & - & - \\
\hline Control (PVS-II) & -0.06 & 0.13 & -0.04 & -0.45 & 0.66 & - & - & - & 0.38 & 2.61 \\
\hline Challenge (PVS-II) & 0.32 & 0.11 & 0.19 & 2.85 & 0.01 & - & - & - & 0.62 & 1.61 \\
\hline Normative commitment (OCS) & 16.93 & 2.98 & - & 5.68 & 0.00 & $2.64 \ddagger$ & $0.01^{* *}+$ & 0.15 & - & - \\
\hline Commitment (PVS-II) & 0.08 & 0.10 & 0.07 & 0.81 & 0.42 & - & - & - & 0.39 & 2.57 \\
\hline Control (PVS-II) & -0.05 & 0.10 & -0.04 & -0.51 & 0.61 & - & - & - & 0.38 & 2.61 \\
\hline Challenge (PVS-II) & 0.17 & 0.09 & 0.13 & 1.91 & 0.05 & - & - & - & 0.62 & 1.61 \\
\hline
\end{tabular}

$N=355$, sample size of employed adults.

$\mathrm{B}$, unstandardised coefficient; SE B, standard error; $\beta$, beta; $t, t$-test; $p$, probability value; $F$, frequency; $R^{2}$, coefficient of determination; $R$, correlation coefficient; $\mathrm{T}$, tolerance; VIF, variance inflation factor; PVS-II, Personal Views Survey II; OCS, Organisational Commitment Scale.

$\dagger$, Constant $(3 ; 351)$.

,$+ R^{2} \leq 0.12$ (small practical effect size).

**, $p \leq 0.01 ;{ }^{* * *}, p \leq 0.001$ 
are in agreement with those of Sezgin (2009) who found hardiness as a significant predictor of all three components of organisational commitment.

The significant relationships between the hardiness variable control and affective-, continuance- and normative commitment components of organisational commitment suggest that participants who are effectively coping with stress (control), are actively involved in their organisation (hardy-commitment) and view change as a tool for their development and growth (challenge), seem more likely to be emotionally attached (affectively committed) to their organistion. These findings are in agreement with Maddi, Harvey, Khoshaba, Fazel and Resurreccion (2009) and Sezgin (2009) who indicate that individuals who are high in hardiness are more likely to experience organisational commitment because they may feel more in control and are actively involved in their organisations, which in turn may ensure that they remain with the organisation.

Similarly, the significant relationship observed between the hardiness variable challenge and affective and continuance commitment suggests that the participants who face up to difficult experiences because they see them as opportunities for personal growth rather than as potential threats to security, are more likely to be committed to the organisation. Moreover, the findings also suggest that those participants who thrive on challenge are motivated to become catalysts in their environment and these participants may be more likely to remain with their current organisation because they regard the costs of leaving the organisation as too high. These findings are in agreement with the findings of Kobasa (1982) and Maddi (1999), which indicated that high challenged individuals are characterised by cognitive flexibility and a tolerance for ambiguity.

The participants were predominantly in the entry and establishment phases of their careers, during which the life structure of young adults become a more stable period as they begin to settle down (Super, 1990). Individuals also become committed to contribute towards an occupation, a company or a person and start to establish socially supportive networks (Greenhaus, Callanan \& Godshalk, 2010). The contention that the young adults' need for developing expertise to change stressful or challenges into opportunities, rather than venturing out toward new and different organisational contexts, seems to be higher during these particular life stages (Coetzee \& Schreuder, 2009). This may offer an explanation for the participants' strong sense of affective-, continuanceand normative commitment. As individuals in the early adulthood phase (entry and establishment life or career stages) become more oriented to the importance of work in their lives and learn how to balance job demands with their own needs (Super, 1990), they generally find the work role becoming increasingly salient (Savickas, 2005). In addition, as shown by the results of the present study, their emotional attachment to the organisation also seems to be stronger. The overall findings of the study add to the employee well- being literature by shedding new light on how hardiness in the human resource management environment relates to their levels of organisational commitment. In practical terms, the new knowledge gained from observing the relationship between hardiness and organisational commitment of the participants may be useful as the study focuses specifically on the South African organisational context.

\section{Conclusion}

The findings of this study have implications for managers and human resource practitioners who are responsible for providing career development support, especially in an employee well-being and subjective work experience context. The findings confirm the need to assess the hardiness of employees, as the notion of developing an employees' hardiness seem to provide valuable information regarding their commitment, control and challenge attributes, which significantly and positively influence their affective-, continuance- and normative commitment.

Individuals who are exposed to positive career experiences will tend to be much more committed towards the organisation (Maddi, 2006). According to Sheard (2009), highly motivated (hardy-commitment) individuals get involved rather than withdraw when situations become stressful, seeing this as the best way to turn their environments and whatever they are experiencing into something that seems interesting, worthwhile, and important. Hardy individuals control their experiences of events in terms of what they choose to do and how they choose to respond (Maddi, 2006). Individuals high in hardy-challenge believe that their lives are improved by means of growth through learning that ease comfort and security (Maddi, 2006). Such individuals may tend to remain with their current organisations seeing that they change their environments and situations to be positive experiences; this in turn will have a positive effect on the well-being of employees.

The findings also highlight the need for further research into the relationship between working adults' hardiness and their organisational commitment, as the percentage variance explained by the prediction model was relatively small in terms of practical effect. However, the practical value of the findings lies in the new knowledge gained with regard to the relationship between the hardiness variables and the factors highlighted as contributing to employees' psychological attachment to the organisation. The statistics further confirmed that both the measures are useful and reliable within the South African context.

Since the present study has been limited to participants predominantly employed in the human resources management field in the South African organisational context, the findings cannot be generalised to other occupational contexts, race or gender groups. Furthermore, given the exploratory nature of the research design, this study can yield no statements about causation. Associations between the variables have thus been interpreted rather than established. 
These findings therefore need to be replicated with broader samples across various occupational groups and economic sectors before more comprehensive conclusions can be drawn about the relationship between employees' hardiness and their organisational commitment.

\section{Acknowledgements Competing interests}

The author declares that she has no financial or personal relationship(s) which may have inappropriately influenced her in writing this paper.

\section{References}

Allen, N., \& Meyer, J. (1990). The measurement and antecedents of affective, continuance and normative commitment to the organisations. Journal of Occupational Psychology, 63, 1-18. http://dx.doi.org/10.1111/j.2044-8325.1990. Occupational
tb00506.x

Avey, J., Luthans, F., Smith, R., \& Palmer, N. (2010). Impact of positive psychological capital on employee well-being over time. Journal of Occupational Health Psychology, 15(1), 17-28. http://dx.doi.org/10.1037/a0016998, PMid:20063956

Azeem, S. (2010). Personality hardiness, job involvement and job burnout among teachers. International Journal of Vocational and Technical Education, 2(3), 36-40.

Barnett, B., \& Bradley, L. (2007). The impact of organisational support for career development on career satisfaction. Career Development International, 12(7), 617-636. http://dx.doi.org/10.1108/13620430710834396

Baruch, Y. (2006). Career development in organisations and beyond: Balancing traditional and contemporary viewpoints. Human Resource Management Review, 16, 125-138. http://dx.doi.org/10.1016/j.hrmr.2006.03.002

Beck, N., \& Wilson, J. (2000). Development of affcetive organizational commitment: A cross-sequental examinations of change with tenure. Journal of Vocational Behaviour, 56, 114-136. http://dx.doi.org/10.1006/jvbe.1999.1712

Breed, M., Cilliers, F., \& Visser, D. (2006). The factor structure of six salutogenic constructs. SA Journal of Industrial Psychology/SA Tydskrif vir Bedryfsielkunde, 32(1), 74-87.

Carr, J., Kelley, B., Keaton, R., \& Albrecht, C. (2011). Getting to grips with stress in the workplace. Human Resource Mangement International Digest, 19(4), 32-38. http://dx.doi.org/10.1108/09670731111140748

Coetzee, M., \& Bergh, Z. (2009). Psychological career resources and subjective work experiences of working adults: An exploratory study. SA Business Review, 13(2) $1-31$.

Coetzee, M., \& Schreuder, D. (2009). Psychological career resources as predictors of working adults' career anchors: An exploratory study. SA Journal of Industria Psychology/SA Tydskrif vir Bedryfsielkunde, 35(1), 1-11.

Coetzee, M., Bergh, Z., \& Schreuder, A. (2010). Subjective work experiences: Exploring the influence of career orientations, psychological career resources and factors of job/career satisfaction/dissatisfaction. Unpublished research report, Department of Industrial and Organisational psychology, University of South Africa, South Africa.

Coetzee, M., Schreuder, D., \& Tladinyane, R. (2007). Career anchors and its relation to organisational commitment. Southern African Business Review, 11(1), 65-86.

Cohen, J. (1992). Statistical power analysis for the behavioural sciences. (2nd edn.). Orlando, FL: Academic Press.

Delahaij, R., Gaillard, A., \& Van Dam, K., (2010). Hardiness and the response to stressful situations: Investigating mediating processes. Journal of Personality and Individual Differences, 49, 386-390. http://dx.doi.org/10.1016/j.paid.2010.04.002

Emberland, J., \& Rundmo, T. (2010). Implications of job insecurity perceptions and job insecurity responses for psychological wel-being, turnover intentions and reported risk behavior. Safety Science, 48, 452-459. http://dx.doi.org/10.1016/j. ssci.2009.12.002

Ferreira, N. (2009). The relationship between psychological career resources and organisational commitment. Unpublished master's thesis, University of Pretoria, Pretoria, South Africa.

Ferreira, N., Basson, J., \& Coetzee, M. (2010). Psychological career resources in relation to organisational commitment: An exploratory study. SA Journal of Human Resource Management/SA Tydskrif vir Menslikehulpbronbestuur, 8(1) $1-9$.

Florian, V., Mikulincer, M., \& Taubman, O. (1995). Does hardiness contribute to mental health during a stressful real-life situation? The roles of appraisal and coping. Journal of Personality and Social Psychology, 68(4), 687-695. http://dx.doi. org/10.1037/0022-3514.68.4.687, PMid:7738771

Fox, C., \& Jones, J. (1998). Uses of the Rasch modeling in counceling psychology research. Journal of Counseling Psychology, 45(1), 30-45. http://dx.doi. org/10.1037/0022-0167.45.1.30

Gbadamosi, G. (2003). HRM and the commitment rethoric. Challenges for Africa. Management Decision, 41(3), 274-280. http://dx.doi.org/10.1108/ 00251740310475218
Gottfredson, G., \& Duffy, R. (2008). Using a theory of vocational personalities and work environments to explore subjective well-being. Journal of Career Assessment, 16(1), 44-59. http://dx.doi.org/10.1177/1069072707309609

Greenhaus, J., Callanan, G., \& Godshalk. (2010). Career management. New York: Harcourt College Publishers.

Hart, P. (1999). Predicting employee life satisfaction: A coherent model of personality, work and non-work experiences and domain satisfaction. Journal of Applied Psychology, 84, 564-584. http://dx.doi.org/10.1037/0021-9010.84.4.564

Holbeche, L. (1997). Career development: The impact of flatter structures on careers. Great Britian: Butterworth-Heinemann

Hughes, L., \& Half, R. (2009). The war of talent. Retrieved May 14, 2009, from http:// www.globalexpertbase.com/wp-8-212.html

Hystad, S., Eid, J., Laberg, J., Johnsen, B., \& Bartone, P. (2010). Academic stress and health: Exploring the moderating role of personality hardiness. Scandinavian Journal of Educational Research, 53, 421-429. http://dx.doi. org/10.1080/00313830903180349

Katz, D., \& Kahn, R. (1978). The social psychology of organizations. (2nd edn.). New York: Wiley.

Kelloway, E., \& Barling, J. (1991). Job characteristics, role stress and menta health. Journal of Occupational Psychology, 64, 291-304. http://dx.doi. org/10.1111/j.2044-8325.1991.tb00561.x

Kelloway, E., Innes, M., Barling, J., Francis, L., \& Turner, N. (2010). Loving one's job: Construct development and implications for individual well-being. Research in Occupational Stress and Well Being, 8, 109-136. http://dx.doi.org/10.1108/ S1479-3555(2010)0000008006

Kidd, J. (2008). Exploring components of career well-being and the emotions associated with significant career experiences. Journal of Career Development 35(2), 166-186. http://dx.doi.org/10.1177/0894845308325647

Kobasa, S. (1979). Personality and resistance to illness. American Journal of Community Psychology, 7(4), 413-423. http://dx.doi.org/10.1007/BF00894383, PMid:495583

Kobasa, S. (1982). The hardy personality: Toward a social psychology of stress and health. In G.S. Sanders \& J. Suls (Eds.), Social psychology of healh and illness, (pp. 214-219). Hillsdale, NJ: Lawrence Erlbaum Associates.

Kobasa, S. (1987). Stress responses and personality. In R.C. Barnette \& L. Biener (Eds.), Gender and Stress, (n.p.). New York: The Free Press.

Kobasa, S. (1985). Barriers to work stress II: The Hardy personality. In W.D. Gentry, H. Benson \& C.J. de Wolff (Eds.), Behavioural medicine: Work stress and health, (pp. 181-204). Dordrecht/Boston/Lancaster: Martinus Nijhoff Publishers.

Kobasa, S., \& Puccetti, M. (1983). Personality and social resources in stress resistance. Journal of Personality and Social Psychology, 45(4), 839-850. http://dx.doi. Journal of Personality and Social Psychology, 4
org/10.1037/0022-3514.45.4.839, PMid:6631665

Kobasa, S., Maddi, S., \& Kahn, S. (1982). Hardiness and health: A prospective study. Jorunal of Personality and Social Psychology, 42, 168-177. http://dx.doi. org/10.1037/0022-3514.42.1.168, PMid:7057354

Kobasa, S., Maddi, S., \& Zola, M. (1985). Type A and hardiness. Journal of Behvaioura Medicine, 6(1), 41-51. http://dx.doi.org/10.1007/BF00845275, PMid:6876154

Lumley, E. (2010). The relationship between career anchors, job satisfaction and organisational commitment. Master's dissertation, Department of Industrial and Organisational Psychology, University of South Africa, South Africa.

Lumley, E., Coetzee, M., Tladinyane, E., \& Ferreira, N. (2011). Exploring the job satisfaction and organisational commitment of employees in the information technology environment. Southern Arican Business Review, 15(1), 100-118.

Maddi, S. (1987). Hardiness training at Illinois Bell Telephone. In J.P. Opatz (Ed.), Health promotion evaluation: Measuring the organizational impact, (pp 101115). Stevens Point, WI: National Wellness institute.

Maddi, S. (1999). The personality construct of hardiness I: Effect on experiencing, coping, and strain. Consulting Psychology Journal, 51(2), 83-94. http://dx.doi. org/10.1037/1061-4087.51.2.83

Maddi, S. (2002). The story of hardiness: Twenty years if theorizing, research, and practice. Conculting Psychology Journal: Practice and Research, 54(3), 175-185. http://dx.doi.org/10.1037/1061-4087.54.3.173

Maddi, S. (2004). Hardiness: An operationalisation of existential courage. Journa of Humanistic Psychology, 44(3), 279-298. http://dx.doi.org/10.1177/ 0022167804266101

Maddi, S. (2006). Hardiness: The courage to grow from stresses. Journal of Positive Psychology, 1, 160-168. http://dx.doi.org/10.1080/17439760600619609

Maddi, S., \& Khoshaba, D. (2005). Relicience at work. New York: Amacom.

Maddi, S., \& Kobasa, S. (1984). The hardy executive: Health under stress. Chicago, IL: Dorsey professional Books.

Maddi, S., Harvey, R., Khoshaba, D., Fazel, M., \& Resurreccion, N. (2009). The personality construct of Hardiness, IV: Explressed in positive cognitions and emotions concerning oneself and developmentally relavant activities. Journal of Humanistic Psychology, 49(3), 292-305. http://dx.doi.org/10.1177/0022167809331860

Maddi, S., Khoshaba, D., Persico, M., Lu, J., Harvey, R., \& Bleecker, F. (2002). The personality contruct of hardines II: Relationships with comprehensive tests of personality and psychopathology. Journal of Research in Personality, 36, 72-85. http://dx.doi.org/10.1006/jrpe.2001.2337

March, R., \& Mannari, H. (1977). Organisational commitment and turnover: A prediction study. Administrative Science Quarterly, 22, 57-67. http://dx.doi. org/10.2307/2391746

Mathieu, J., \& Zajac, D. (1990). A review and meta-analysis of the antecedents, correlates and consequences of organisational commitment. Psychological Bulletin, 108(2), 171-194. http://dx.doi.org/10.1037/0033-2909.108.2.171 
Mester, C., Visser, D., Roodt, G., \& Kellerman, R. (2003). Leadership style and its relation to employee attitudes and behaviour. SA Journal of Industrial Psychology/ SA Tydskrif vir Bedryfsielkunde, 29(2), 72-82.

Meyer, J., \& Allen, N. (1991). A three component conceptialization of organisationa commitment. Human Resource Management Review, 1, 61-89. http://dx.doi. org/10.1016/1053-4822(91)90011-Z

Meyer, J., \& Allen, N. (1997). Commitment in the wokrplace, theory, reserach and application. California: Sage.

Meyer, J., \& Maltin, E. (2010). Employee commitment and well-being: A critical review, theoretical framework and research agenda. Journal of Vocational Behaviour, 77, 323-337. http://dx.doi.org/10.1016/j.jvb.2010.04.007

Meyer, J., Stanley, D., Herscovitch, L., \& Topolnytsky, L. (2002). Affective, continuance and normative commitment to the organization: A meta-analysis of antecendents, correlates, and consequences. Journal of Vocational Behavior, 61, 20-52. http:// dx.doi.org/10.1006/jvbe.2001.1842

Mills, L. (2000). Evaluation of a model of hardiness and health using meta-analysis and path analysis. Unpublished Dissertation, University of Tulsa, Oklahoma, USA.

Nabi, G. (2001). The relationship between HRM, social support and subjective career success among men and women. International Journal of Manpower, 22(5), 457474. http://dx.doi.org/10.1108/EUM0000000005850

Rathi, N., Rastogi, R., \& Rangnekar, D. (2011). Quality of work life, organisational commitment, and psychological well-being. A study of the Indian employees. International Journal of Contemporary Business Studies, 2(4), 2156-7506.

Rhodewalt, F., \& Zone, J. (1989). Appraisal of life changem depression, and illness in hardy and nonhardy women. Journal of Personality and Social Psychology, 56(1), 81-88. http://dx.doi.org/10.1037/0022-3514.56.1.81, PMid:2926618

Russ, F., \& McNeilly, K. (1995). Links among satisfaction, commitment and turnover intentions: The moderating effect of experience, gender and performance. Journal of Business Research, 513, 57-65. http://dx.doi.org/10.1016/0148 2963(94)00042-D

Saks, A. (2006). Antecendents and consequences of employee engagement Journal of Managerial Psychology, 21(7), 600-619. http://dx.doi.org/10.1108/ 02683940610690169
Savickas, M. (2005). The theory and practice of career construction. In S.D. Brown \& R.W. Lent (Eds) Career development and counseling (pp. 101-108). Hoboken, New Jersey: John Wiley \& Sons, Inc

Schreuder, A., \& Coetzee, M. (2011). Careers: An organisational perspective. (4th edn.). Cape Town: Juta.

Sezgin, F. (2009). Relationship between teacher organisatinal commitment, psychological hardiness and some demographic variables in Turkish primary schools. Journal of Educational Administration, 47(5), 630-651. http://dx.doi. org/10.1108/09578230910981099

Sheard, M. (2009). Hardiness commitment, gender, and age differentiate university adacemic performance. British Journal of Educational Psychology, 79, 189-204. http://dx.doi.org/10.1348/000709908X304406, PMid:18466672

Sheard, M., \& Golby, J. (2007). Hardiness and undergraduate academic study: The moderating role of commitment. Personality and Individual Differences, 43, 579588. http://dx.doi.org/10.1016/j.paid.2007.01.006

Sparks, K., Faragher, B., \& Cooper, C. (2001). Well-being and occupational health in the 21st century workplace. Journal of Occupational and Organizational Psychology, 74(4), 489-509. http://dx.doi.org/10.1348/096317901167497

Super, D. (1990). A life-span approach to career development. In D. Brown (Ed.) (2007). Career Information, Career Counselling and Career Development. (9th edn.). United States of America: Pearson.

Tillich, P. (1952). The courage to be. New Haven, CT: Yale University Press.

Westman, M. (1990). The relationship between stress and performance: The moderating effect of hardiness. Human Performance, 3(3), 141-155. http:// dx.doi.org/10.1207/s15327043hup0303_1

Wiebe, D. (1991). Hardiness and stress moderation: A test of proposed mechanisms Journal of Personality and Social Psychology, 60(1), 89-99. http://dx.doi. org/10.1037/0022-3514.60.1.89, PMid:1995836

Zakin, G., Solomon, Z., \& Neria, Y. (2003). Hardiness, attachment stryle, and long term psychological distress among Israeli POWs and combat veterans. Journal of Personality and Individual Differences, 34, 819-829. http://dx.doi.org/10.1016/ S0191-8869(02)00073-9

Zhang, L. (2010). Hardiness and the Big five personality traits among Chinese university students. Journal of Learning and Individual Differences, 1-5. 